\title{
Effectiveness of three different luteinizing hormone-releasing hormone agonists in the chemical castration of patients with prostate cancer: Goserelin versus triptorelin versus leuprolide
}

\author{
Myungsun Shim, Woo Jin Bang, Cheol Young Oh, Yong Seong Lee, Jin Seon Cho \\ Department of Urology, Hallym University Sacred Heart Hospital, Hallym University College of Medicine, Anyang, Korea
}

Purpose: To investigate the changes in testosterone levels and rates of chemical castration following androgen-deprivation therapy (ADT) with goserelin, triptorelin, and leuprolide.

Materials and Methods: We retrospectively reviewed the medical records of 125 patients with prostate cancer treated with luteinizing hormone-releasing hormone (LHRH) agonists between January 2009 and December 2015. Changes in testosterone concentration during 9 months of ADT with goserelin $11.34 \mathrm{mg}$, triptorelin $11.25 \mathrm{mg}$, and leuprolide $11.25 \mathrm{mg}$ were analyzed using a mixed model. The number of patients with serum testosterone below castration levels defined as various values $(<50 \mathrm{ng} / \mathrm{dL},<20$ $\mathrm{ng} / \mathrm{dL}$, or $<10 \mathrm{ng} / \mathrm{dL}$ ) at 3, 6, and 9 months were also evaluated.

Results: Of the 125 patients, 59 received goserelin, 44 received triptorelin, and 22 received leuprolide, respectively. The lowest mean testosterone levels during 9 months of treatment were achieved in patients treated with triptorelin, followed by those treated with leuprolide, and then by those treated with goserelin $(p=0.001)$. Significant differences in chemical castration levels were observed only at $<10 \mathrm{ng} / \mathrm{dL}$, with $54.2 \%$ of goserelin, $93.2 \%$ of triptorelin, and $86.4 \%$ of leuprolide treated patients ( $<<0.001$ ).

Conclusions: Three LHRH agonists showed comparable efficacy for achieving castration when the castration threshold was 50 or $20 \mathrm{ng} / \mathrm{dL}$. However, triptorelin was the most potent LHRH agonist, achieving the lowest mean testosterone levels and the highest rate of chemical castration at $<10 \mathrm{ng} / \mathrm{dL}$ testosterone.

Keywords: Antineoplastic agents; Prostatic neoplasms; Prostate-specific antigen; Testosterone

This is an Open Access article distributed under the terms of the Creative Commons Attribution Non-Commercial License (http://creativecommons.org/licenses/by-nc/4.0) which permits unrestricted non-commercial use, distribution, and reproduction in any medium, provided the original work is properly cited.

\section{INTRODUCTION}

Androgen-deprivation therapy (ADT) is an effective treatment for advanced and metastatic prostate cancer, with progression-free survival of 12 to 30 months in approximately 90\% of patients [1] Androgen deprivation can be achieved by

Received: 22 January, 2019 - Accepted: 28 March, 2019

Corresponding Author: Jin Seon Cho

Department of Urology, Hallym University Sacred Heart Hospital, 22 Gwanpyeong-ro 170beon-gil, Dongan-gu, Anyang 14068, Korea

TEL: +82-31-380-3850, FAX: +82-31-380-3852, E-mail: js315@hallym.or.kr

ORCID: https://orcid.org/0000-0003-0429-191X 
bilateral orchiectomy, antiandrogens, or luteinizing hormonereleasing hormone (LHRH) agonists. Although effective, surgical castration is invasive and has a negative impact on the patient's psychological condition. Antiandrogens are well tolerated; however, they are associated with worse survival outcomes than other treatment options when used alone [2] Because it is much better accepted by patients than surgical castration and has equivalent survival rates after treatment, LHRH agonist treatment is mostly preferred ADT for many patients [2]. Therefore, since their introduction in the 1980s, LHRH agonists have become the most widely used treatment of advanced/metastatic prostate cancer, and an alternative to surgical castration [3].

$\mathrm{LHRH}$ is secreted by the hypothalamus and its original role is to stimulate both the synthesis and the secretion of luteinizing hormone $(\mathrm{LH})$ and follicle-stimulating hormone by the pituitary gland [4]. However, continuing administration of LHRH agonist down-regulates LHRH receptor and causes post-receptor desensitization of gonadotropic cells after a transitory hyper-stimulation phase, resulting in the blockade of testosterone production by Leydig cells in the testis $[5,6]$. Even though LHRH agonists are usually effective for androgen deprivation though this mechanism, differences in their amino acid structure may affect the degree of inhibition of the pituitary-gonadal axis and their castration potency. Some LHRH agonists, leuprolide acetate in particular, may not always suppress serum testosterone below the upper limit of the castration level $[7,8]$.

Therefore in this study, we aimed to evaluate the effectiveness of goserelin, triptorelin, and leuprolide, which are the LHRH agonists most widely used in the clinical practice to treat advanced/metastatic prostate cancer. We assessed the efficacy of these three agents by comparing the mean testosterone levels and the ability to induce castration levels of serum testosterone during 9 months of treatment.

\section{MATERIALS AND METHODS}

The study was performed with the approval and oversight of the Institutional Review Board of the Hallym University Sacred Heart Hospital (approval number: 2017-I065). Written informed consent for this study was waived due to its retrospective nature. The medical records of 125 patients with histologically documented, locally advanced or metastatic prostate cancer treated with LHRH agonists between January 2009 and December 2015 were evaluated. Patients with abnormal serum testosterone concentrations of $<1.8 \mathrm{ng} / \mathrm{mL}$ or $>8.8 \mathrm{ng} /$ $\mathrm{mL}$, hypophysectomy, adrenalectomy, orchiectomy, other malignancies, alcohol dependence, using medications that affect metabolism or secretion of steroid hormones, using corticosteroids, treated by intermittent androgen blockade, or with inappropriate follow-up were excluded. One of three LHRH agonists, goserelin acetate $11.34 \mathrm{mg}$, triptorelin acetate $11.25 \mathrm{mg}$, or leuprolide acetate $11.25 \mathrm{mg}$, was administered at 3-month intervals. Serum testosterone level was assayed immediately before ADT treatment and at 3, 6, and 9 months after treatment began. Serum testosterone was assayed by electrochemiluminescence (Elecsys ${ }^{\circledR}$ Testosterone II; Roche Diagnostics GmbH, Mannheim, Germany) and an immunoassay analyzer (Cobas ${ }^{\circledR}$; Roche Diagnostics $\mathrm{GmbH}$ ). Patients' baseline characteristics including age, body mass index (BMI), prostate-specific antigen (PSA), prostate volume measured by transrectal ultrasonography, biopsy Gleason score, distant metastasis, and concomitant anti-androgen use were recorded. The mean serum testosterone level at 3,6 , and 9 months and the number of patients with serum testosterone level below castration levels of $<50,<20$, and $<10$ $\mathrm{ng} / \mathrm{dL}$ at 3, 6, and 9 months, in response to each of the three agents was compared. Adverse events related to LHRH agonists were monitored throughout the study period and the severity was recorded following the common terminology criteria for adverse events version 4.0 (CTCAE ver. 4.0) [9].

\section{Statistical analysis}

Categorical and continuous baseline characteristics were compared using chi-squared tests $\left(\chi^{2}\right)$ or one-way analysis of variance (ANOVA). Changes in serum testosterone concentration throughout the study period were analyzed by a mixed model. The proportions of chemically castrated patients in the three groups at 3, 6, and 9 months after ADT initiation and the proportion of patients with adverse effects were compared by one-way ANOVA. All tests were done using SAS ${ }^{\circledR}$ Proprietary Software 9.3 (SAS Institute Inc, Cary, NC, USA), and a p-value $<0.05$ was considered to be statistically significant.

\section{RESULTS}

\section{Patient characteristics}

Of the 125 patients with prostate cancer who met the inclusion/exclusion criteria, 59 were treated with goserelin, 44 with triptorelin, and 22 with leuprolide. The median age, BMI, PSA, testosterone before ADT, and prostate volume was 76.0 years, $23.5 \mathrm{~kg} / \mathrm{m}^{2}, 135.0 \mathrm{ng} / \mathrm{mL}, 4.3 \mathrm{ng} / \mathrm{mL}$, and 50.0 $\mathrm{mL}$ respectively. These baseline characteristics did not differ significantly in the three groups ( $>>0.05$ ). The biopsy Gleason scores and percentage of distant metastasis in the three 
groups were not significantly different $(\mathrm{p}>0.2)$. Maximal androgen blockade (MAB, bicalutamide+LHRH agonists) was received by $55.9 \%$ of goserelin- and $56.8 \%$ of triptorelintreated patients, and a significantly smaller percentage of leuprolide-treated patients (18.2\%) received MAB. The clinical and pathological characteristics are summarized in Table 1. In addition, there was no difference in the degree of PSA reduction between the three drugs, throughout the study period.

\section{Change in serum testosterone level with the three LHRH agonists over time}

The changes in testosterone level observed in the three treatment groups are shown in Fig. 1. The mean testosterone concentration \pm standard deviation in patients treated with triptorelin decreased continuously and remained the lowest throughout the study period, reaching $7.0 \pm 7.6 \mathrm{ng} / \mathrm{dL}$ at 3 months, $5.9 \pm 4.3 \mathrm{ng} / \mathrm{dL}$ at 6 months, and $5.7 \pm 4.2 \mathrm{ng} / \mathrm{dL}$ at 9 months. A similar change was observed in patients treated with leuprolide and the corresponding values were $9.7 \pm 9.4$, $8.6 \pm 6.6$, and $8.0 \pm 7.9 \mathrm{ng} / \mathrm{dL}$. The values for goserelin were $11.9 \pm 12.1 \mathrm{ng} / \mathrm{dL}$ at 3 months, $9.9 \pm 6.5 \mathrm{ng} / \mathrm{dL}$ at 6 months, and $12.7 \pm 13.6 \mathrm{ng} / \mathrm{dL}$ at 9 months, showing that the testosterone concentration decreased from 3 to 6 months, but increased from 6 to 9 months after treatment (Fig. 1A). The mean testosterone concentrations over time were significantly different in patients treated with triptorelin and those treated with goserelin $(p<0.001)$, but the differences between leuprolide and goserelin $(\mathrm{p}=0.087)$ and triptorelin and leuprolide ( $\mathrm{p}=0.106$ ) were not significant (Fig. 1A). The results of a subanalysis of patients with LHRH monotherapy were similar. The mean serum testosterone levels were the

Table 1. Patient characteristics

\begin{tabular}{|c|c|c|c|c|}
\hline Variable & Goserelin $(n=59)$ & Triptorelin $(n=44)$ & Leuprolide $(n=22)$ & p-value \\
\hline Age (y) & $76.2 \pm 6.8$ & $75.0 \pm 6.8$ & $77.5 \pm 8.4$ & 0.539 \\
\hline Body mass index $\left(\mathrm{kg} / \mathrm{m}^{2}\right)$ & $23.3 \pm 3.5$ & $22.4 \pm 3.3$ & $23.8 \pm 3.5$ & 0.607 \\
\hline PSA before castration (ng/mL) & $123.3 \pm 205.5$ & $193.4 \pm 324.9$ & $90.4 \pm 164.2$ & 0.169 \\
\hline Testosterone before castration (ng/mL) & $4.3 \pm 1.1$ & $4.1 \pm 1.2$ & $4.7 \pm 1.5$ & 0.079 \\
\hline Prostate volume (mL) & $54.7 \pm 31.3$ & $42.0 \pm 17.4$ & $52.1 \pm 38.8$ & 0.728 \\
\hline Gleason score & & & & 0.504 \\
\hline$\leq 6$ & $9(15.3)$ & $3(6.8)$ & $3(13.6)$ & \\
\hline 7 & $11(18.6)$ & $5(11.4)$ & $3(13.6)$ & \\
\hline$\geq 8$ & $39(66.1)$ & $36(81.8)$ & $16(72.7)$ & \\
\hline Distant metastasis & $54(91.5)$ & $39(88.6)$ & $19(86.4)$ & 0.248 \\
\hline Patients with MAB & $33(55.9)$ & $25(56.8)$ & $4(18.2)$ & 0.005 \\
\hline
\end{tabular}

Values are presented as mean \pm standard deviation or number (\%). PSA, prostate-specific antigen; MAB, maximal androgen blockade.
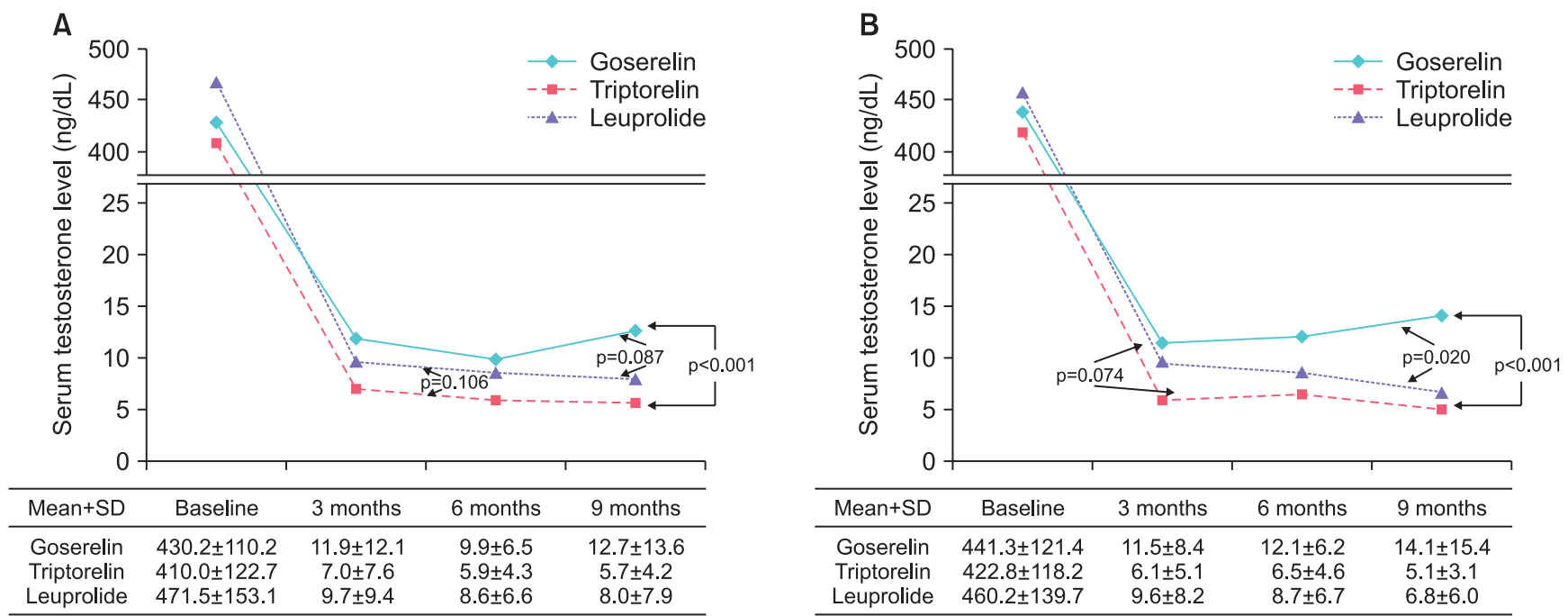

Fig. 1. Mean serum testosterone level after androgen-deprivation therapy according to different luteinizing hormone-releasing hormone (LHRH) agonists. (A) Total, (B) patients with LHRH monotherapy. SD, standard deviation. 
lowest in patients treated with triptorelin $(6.1 \pm 5.1 \mathrm{ng} / \mathrm{dL}$ at 3 months, $6.5 \pm 4.6 \mathrm{ng} / \mathrm{dL}$ at 6 months, and $5.1 \pm 3.1 \mathrm{ng} / \mathrm{dL}$ at 9 months), followed by leuprolide (9.6 $\pm 8.2,8.7 \pm 6.7$, and $6.8 \pm 6.0$ $\mathrm{ng} / \mathrm{dL})$ and goserelin $(11.5 \pm 8.4,12.1 \pm 6.2$, and $14.1 \pm 15.4 \mathrm{ng} / \mathrm{dL})$. The mean testosterone concentrations in patients treated with goserelin were the lowest at 3 months, but increased thereafter. Patients who received triptorelin and leuprolide had significantly lower mean serum testosterone values than those treated with goserelin $(p<0.001$ and $p=0.020$, respectively, Fig. 1B).

\section{Percentage of chemically castrated patients at each cutoff value}

At $50 \mathrm{ng} / \mathrm{dL}$, chemical castration was not observed in one patient at 3 and 9 months who received goserelin. Chemical castration was maintained by all patients who received triptorelin and leuprolide, and at $50 \mathrm{ng} / \mathrm{dL}$, there were no significant differences among the group (Table 2, $\mathrm{p}=0.768$ ). The result was similar in the LHRH monotherapy subanalysis, with one patient on goserelin having a testosterone concentration $>50 \mathrm{ng} / \mathrm{dL}$ at 9 months (Table 2, $\mathrm{p}=0.897$ ). Comparable results were obtained when the cutoff value was set at $20 \mathrm{ng} / \mathrm{dL}$, with chemical castration $>90 \%$ of all patients (Table $2, \mathrm{p}=0.283$ ), including the monotherapy subanalysis (Table 2, $\mathrm{p}=0.684$ ). At a cutoff of $10 \mathrm{ng} / \mathrm{dL}$, chemical castration was observed in $93.2 \%$ of triptorelinand $86.4 \%$ of leuprolide-treated patients at 9 months, but it was significantly lower at $54.2 \%$ in patients treated with goserelin (Table $2, \mathrm{p}<0.001$ ). In the monotherapy subanalysis, percentages of chemically castrated patients at 9 months were $89.5 \%$ with triptorelin, $83.3 \%$ with leuprolide, and 34.6 $\%$ with goserelin (Table $2, \mathrm{p}<0.001$ ).

\section{Adverse events associated with LHRH agonists}

Among the 125 patients included in the analysis, 7 patients experienced clinically significant event related to the skeletal system, 6 experienced facial flushing, and severe osteoporosis and cardiovascular adverse events were reported in one patient each. No patient had to discontinue LHRH agonist treatment because of adverse events. The adverse event rate was higher with goserelin, but the difference was not statistically significant (Table 3).

\section{DISCUSSION}

The currently established threshold for standard castration is a testosterone level of $50 \mathrm{ng} / \mathrm{dL}(1.7 \mathrm{nmol} / \mathrm{L})$, and it has been used as a treatment guideline for managing prostate cancer with ADT over 4 decades [10]. The 2016 National Comprehensive Cancer Network (NCCN) guidelines

Table 2. Number (\%) of patients with different castration levels of serum testosterone at 3, 6, and 9 months after treatment with LHRH agonists

\begin{tabular}{|c|c|c|c|c|c|}
\hline Testosterone level & LHRH agonists & 3 months & 6 months & 9 months & p-value ${ }^{a}$ \\
\hline \multicolumn{6}{|l|}{ Total } \\
\hline \multirow[t]{3}{*}{$50 \mathrm{ng} / \mathrm{dL}$} & Goserelin $(n=59)$ & $58(98.3)$ & $59(100.0)$ & $58(98.3)$ & 0.768 \\
\hline & Triptorelin $(n=44)$ & $44(100.0)$ & $44(100.0)$ & $44(100.0)$ & \\
\hline & Leuprolide ( $n=22$ ) & $22(100.0)$ & $22(100.0)$ & $22(100.0)$ & \\
\hline \multirow[t]{3}{*}{$20 \mathrm{ng} / \mathrm{dL}$} & Goserelin $(n=59)$ & $55(93.2)$ & $58(98.3)$ & $55(93.2)$ & 0.283 \\
\hline & Triptorelin $(n=44)$ & $41(93.2)$ & $44(100.0)$ & $44(100.0)$ & \\
\hline & Leuprolide $(n=22)$ & $20(90.9)$ & $20(90.9)$ & $21(95.5)$ & \\
\hline \multirow[t]{3}{*}{$10 \mathrm{ng} / \mathrm{dL}$} & Goserelin $(n=59)$ & $19(32.2)$ & $22(37.3)$ & $32(54.2)$ & $<0.001$ \\
\hline & Triptorelin $(n=44)$ & $33(75.0)$ & $35(79.5)$ & $41(93.2)$ & \\
\hline & Leuprolide ( $n=22)$ & $13(59.1)$ & $12(54.5)$ & $19(86.4)$ & \\
\hline \multicolumn{6}{|c|}{ Patients with LHRH monotherapy } \\
\hline \multirow[t]{3}{*}{$50 \mathrm{ng} / \mathrm{dL}$} & Goserelin $(n=26)$ & $26(100.0)$ & $26(100.0)$ & $25(96.2)$ & 0.897 \\
\hline & Triptorelin (n=19) & $19(100.0)$ & $19(100.0)$ & $19(100.0)$ & \\
\hline & Leuprolide ( $n=18)$ & $18(100.0)$ & $18(100.0)$ & $18(100.0)$ & \\
\hline \multirow[t]{3}{*}{$20 \mathrm{ng} / \mathrm{dL}$} & Goserelin ( $n=26)$ & $25(96.2)$ & $25(96.2)$ & $24(92.3)$ & 0.684 \\
\hline & Triptorelin $(n=19)$ & $19(100.0)$ & $19(100.0)$ & $19(100.0)$ & \\
\hline & Leuprolide ( $n=18$ ) & $17(94.4)$ & $17(94.4)$ & $18(100.0)$ & \\
\hline \multirow[t]{3}{*}{$10 \mathrm{ng} / \mathrm{dL}$} & Goserelin ( $n=26)$ & $6(23.1)$ & $5(19.2)$ & $9(34.6)$ & $<0.001$ \\
\hline & Triptorelin $(n=19)$ & $15(78.9)$ & $13(68.4)$ & 17 (89.5) & \\
\hline & Leuprolide $(n=18)$ & $10(55.6)$ & $9(50.0)$ & $15(83.3)$ & \\
\hline
\end{tabular}

$\mathrm{LHRH}$, luteinizing hormone-releasing hormone.

a:p-value at 9 months. 
Table 3. Adverse events associated with three different LHRH agonists

\begin{tabular}{lccc}
\multicolumn{1}{c}{ Event } & Goserelin $(\mathrm{n}=59)$ & Triptorelin $(\mathrm{n}=\mathbf{4 4})$ & Leuprolide $(\mathrm{n}=\mathbf{2 2})$ \\
\hline Skeletal-related events & 5 & 1 & 1 \\
Flushing & 3 & 1 & 2 \\
Osteoporosis & 1 & 0 & 0 \\
Cardiovascular & 1 & 0 & 0 \\
\hline
\end{tabular}

$\mathrm{LHRH}$, luteinizing hormone-releasing hormone.

also recommend a $50 \mathrm{ng} / \mathrm{dL}$ threshold [11]. The $50 \mathrm{ng} / \mathrm{dL}$ threshold has persisted because the limited accuracy of the standard double isotope-derivative dilution assay, which cannot reliably measure serum testosterone concentration of $<50 \mathrm{ng} / \mathrm{dL}$ [12]. However, a new assay and the availability of newly developed LHRH agonists make it possible to change the threshold. Since it was approved for clinical use in 1996 [13], the chemiluminescent assay has become the preferred serum testosterone assay. It is more accurate than the previous assay [12] and has been shown to detect a mean $16 \mathrm{ng} / \mathrm{dL}$ concentration in a group of 35 men with bilateral orchiectomy, far lower than the current $50 \mathrm{ng} / \mathrm{dL}$ threshold [10]. Now that we have more refined ways for measuring testosterone, several reports proposed revising the definition of chemical castration $[10,14,15]$. However, establishing a threshold testosterone level of $<20 \mathrm{ng} / \mathrm{dL}$, using orchiectomy as a benchmark, would depend on expectation of better therapeutic outcomes.

There is a concern that relatively high testosterone levels related to inadequate androgen suppression might result in higher prostate cancer mortality. Breakthrough increases of serum testosterone, i.e., testosterone escape, during $\mathrm{ADT}$ are not only frequent but also linked to PSA progression [14]. Fewer escapes and/or lower testosterone levels have been correlated with a reduced probability of developing castration-resistant prostate cancer [14,16]. A decreased time to castration-resistance has also been associated with increased serum testosterone in patients with prostate cancer receiving ADT [14,17], and 6-month serum testosterone level was found to be an independent predictor of cancer-specific survival in patients with metastatic prostate cancer treated with ADT [18]. Testosterone level in chemically castrated patients may thus have a prognostic value regarding castration-resistance progression, and low serum testosterone may have a beneficial effect in patients with ADT. If it is possible to measure testosterone levels lower than $50 \mathrm{ng} / \mathrm{dL}$ and if patients may benefit from lower testosterone level, it is reasonable to lower the threshold for chemical castration.

A possible change in the threshold makes it important to find out whether the currently available LHRH agonists differ in effectiveness for obtaining chemical castration at a new, lower threshold. In comparing the potency for lowering serum testosterone levels of different LHRH agonist, a recent study reported mean serum testosterone levels after 3 months of treatment were the lowest with leuprolide $7.5 \mathrm{mg}$, followed by goserelin $3.7 \mathrm{mg}$ and leuprolide $3.75 \mathrm{mg}$ [19]. Another study found that maintenance of castration was better with triptorelin pamoate $3.75 \mathrm{mg}$ than leuprolide acetate $7.5 \mathrm{mg}$, but the difference was not statistically significant [7]. Most previous studies have found no, or only small, differences among LHRH agonists when the castration threshold was $50 \mathrm{ng} / \mathrm{dL}[3,11,20]$. However, lowering the threshold to $20 \mathrm{ng} / \mathrm{dL}$ was found to result in a significantly lower castration failure rate with high-dose 7.5 $\mathrm{mg}$ leuprolide compared with low-dose $3.75 \mathrm{mg}$ leuprolide or $3.6 \mathrm{mg}$ goserelin [3]. Oefelein and Cornum [20] found that 5\% of patients failed to achieve castration levels at a $50 \mathrm{ng} / \mathrm{dL}$ threshold, but that increased to $13 \%$ at a threshold of $20 \mathrm{ng} /$ $\mathrm{dL}$. It is thus likely that lowering the castration threshold to $20 \mathrm{ng} / \mathrm{dL}$, or even $10 \mathrm{ng} / \mathrm{dL}$, would be able to differentiate the effectiveness of the available LHRH agonists to lower serum testosterone level. A threshold of $10 \mathrm{ng} / \mathrm{dL}$ was included in this analysis to further distinguish the efficacy of the evaluated LHRH agonists.

Our data demonstrated the lowest serum testosterone level throughout the study period was achieved by triptorelin treatment, followed by treatment with leuprolide, and goserelin. There were no differences in the rates of achieving castration level at $<50 \mathrm{ng} / \mathrm{dL}$ or $20 \mathrm{ng} / \mathrm{dL}$. However, at a threshold of $10 \mathrm{ng} / \mathrm{dL}$, the percentage of patients maintaining castration level concentrations was highest in patients treated with triptorelin, followed by leuprolide, and goserelin. The results support triptorelin as the most potent of the three agents in lowering serum testosterone level.

Study limitations include its retrospective design, small sample size, and different time of testosterone measurements. As neither therapeutic effect nor survival benefit of a lower threshold could be demonstrated, despite evidence of the beneficial effect of low testosterone, its association with survival is still controversial [21]. We also could not include the statistical comparison of different 
effects of drugs including adverse effects due to the small sample size. However, the most important advantages of this study are the demonstration of the testosterone kinetics of three different LHRH agonists in a single report and the analysis of chemical castration with a novel cutoff value of $<10 \mathrm{ng} / \mathrm{dL}$. The low cutoff may have clinical implications, because a previous study revealed that the mean testosterone level of orchiectomized patients was $<20$ $\mathrm{ng} / \mathrm{dL}$. A large, randomized, prospective study is warranted to further validate the clinical significance of this novel, low threshold for castration level of serum testosterone.

\section{CONCLUSIONS}

A castration threshold of $<50 \mathrm{ng} / \mathrm{dL}$ serum testosterone may not be the optimal value because of evidence of a survival advantages with maintaining a much lower testosterone level in patients with prostate cancer. Triptorelin showed the lowest mean testosterone level up to 9 months of treatment and the highest percentage of chemical castration when the serum testosterone threshold was $<10 \mathrm{ng} / \mathrm{dL}$. Triptorelin may be the most potent castrating agent, but the benefit of maintaining the testosterone level at such a low level is yet to be discovered.

\section{CONFLICTS OF INTEREST}

The authors have nothing to disclose.

\section{ACKNOWLEDGMENTS}

This research was supported by Hallym University Research Fund 2016 (HURF-206-36).

\section{REFERENCES}

1. Denis L, Murphy GP. Overview of phase III trials on combined androgen treatment in patients with metastatic prostate cancer. Cancer 1993;72(12 Suppl):3888-95.

2. Seidenfeld J, Samson DJ, Hasselblad V, Aronson N, Albertsen PC, Bennett CL, et al. Single-therapy androgen suppression in men with advanced prostate cancer: a systematic review and meta-analysis. Ann Intern Med 2000;132:566-77.

3. Dias Silva É, Ferreira U, Matheus W, Faria EF, Silva GD, Saito M, et al. Goserelin versus leuprolide in the chemical castration of patients with prostate cancer. Int Urol Nephrol 2012;44:103944.

4. Schally AV, Arimura A, Kastin AJ, Matsuo H, Baba Y, Redding TW, et al. Gonadotropin-releasing hormone: one polypeptide regulates secretion of luteinizing and follicle-stimulating hormones. Science 1971;173:1036-8.

5. Kiesel L. Molecular mechanisms of gonadotrophin releasing hormone-stimulated gonadotrophin secretion. Hum Reprod 1993;8 Suppl 2:23-8.

6. Stojilkovic SS, Reinhart J, Catt KJ. Gonadotropin-releasing hormone receptors: structure and signal transduction pathways. Endocr Rev 1994;15:462-99.

7. Heyns CF, Simonin MP, Grosgurin P, Schall R, Porchet HC; South African Triptorelin Study Group. Comparative efficacy of triptorelin pamoate and leuprolide acetate in men with advanced prostate cancer. BJU Int 2003;92:226-31.

8. Yri OE, Bjoro T, Fossa SD. Failure to achieve castration levels in patients using leuprolide acetate in locally advanced prostate cancer. Eur Urol 2006;49:54-8; discussion 58.

9. Ishitsuka R, Miyazaki J, Ichioka D, Inoue T, Kageyama S, Sugimoto $\mathrm{M}$, et al. Impact of acute kidney injury defined by CTCAE v4.0 during first course of cisplatin-based chemotherapy on treatment outcomes in advanced urothelial cancer patients. Clin Exp Nephrol 2017;21:732-40.

10. Oefelein MG, Feng A, Scolieri MJ, Ricchiutti D, Resnick MI. Reassessment of the definition of castrate levels of testosterone: implications for clinical decision making. Urology 2000;56:1021-4.

11. Breul J, Lundström E, Purcea D, Venetz WP, Cabri P, Dutailly P, et al. Efficacy of testosterone suppression with sustainedrelease triptorelin in advanced prostate cancer. Adv Ther 2017; 34:513-23.

12. Veldhuis JD, Liem AY, South S, Weltman A, Weltman J, Clemmons DA, et al. Differential impact of age, sex steroid hormones, and obesity on basal versus pulsatile growth hormone secretion in men as assessed in an ultrasensitive chemiluminescence assay. J Clin Endocrinol Metab 1995;80:3209-22.

13. Wheeler MJ, D'Souza A, Matadeen J, Croos P. Ciba Corning ACS:180 testosterone assay evaluated. Clin Chem 1996;42: 1445-9.

14. Morote J, Orsola A, Planas J, Trilla E, Raventós CX, Cecchini $\mathrm{L}$, et al. Redefining clinically significant castration levels in patients with prostate cancer receiving continuous androgen deprivation therapy. J Urol 2007;178:1290-5.

15. Dason S, Allard CB, Tong J, Shayegan B. Defining a new testosterone threshold for medical castration: results from a prospective cohort series. Can Urol Assoc J 2013;7:E263-7.

16. Kamada S, Sakamoto S, Ando K, Muroi A, Fuse M, Kawamura $\mathrm{K}$, et al. Nadir testosterone after long-term followup predicts prognosis in patients with prostate cancer treated with combined androgen blockade. J Urol 2015;194:1264-70.

17. Klotz L, O'Callaghan C, Ding K, Toren P, Dearnaley D, Higano $\mathrm{CS}$, et al. Nadir testosterone within first year of androgen- 
deprivation therapy (ADT) predicts for time to castration-resistant progression: a secondary analysis of the PR-7 trial of intermittent versus continuous ADT. J Clin Oncol 2015;33:11516.

18. Perachino M, Cavalli V, Bravi F. Testosterone levels in patients with metastatic prostate cancer treated with luteinizing hormone-releasing hormone therapy: prognostic significance? BJU Int 2010;105:648-51.

19. Reis LO, Denardi F, Faria EF, Silva ED. Correlation between testosterone and PSA kinetics in metastatic prostate cancer patients treated with diverse chemical castrations. Am J Mens Health 2015;9:430-4.

20. Oefelein MG, Cornum R. Failure to achieve castrate levels of testosterone during luteinizing hormone releasing hormone agonist therapy: the case for monitoring serum testosterone and a treatment decision algorithm. J Urol 2000;164:726-9.

21. Bertaglia V, Tucci M, Fiori C, Aroasio E, Poggio M, Buttigliero C, et al. Effects of serum testosterone levels after 6 months of androgen deprivation therapy on the outcome of patients with prostate cancer. Clin Genitourin Cancer 2013;11:325-30.e1. 